\title{
Finding home: South African migration to New Zealand
}

\author{
Christine Winbush and Rachael Selby
}

\begin{abstract}
An Indian man sits quietly in the Heathrow Airport Terminal. He seems to look at something inside himself and his eyes are empty, inward-looking. After a couple of days the terminal staff start to notice him and ask what he is doing, why does he not go out and leave the terminal like all the other passengers? He answers that he has flown from Bombay to London and is now waiting for his soul to arrive (Antilla, 1995, p. 77).
\end{abstract}

South Africans have migrated to New Zealand either deliberately abandoning their country of birth or drawn to New Zealand as a country opening its arms to them to begin a new life. Leaving home means many do wait for their souls to arrive in their newly adopted home. Many have suffered grief and loss, while adapting and settling into a new country and culture. Most of the families that have come to New Zealand are either of English or Afrikaans background. They bring skills needed in New Zealand and while many have readily adapted there are many who have struggled with the change. This paper addresses the issue of culture shock and other associated tensions experienced by South African migrants with Afrikaans as their first language. Themes addressed in this article emerged from a review of the literature and in the course of a research project. They represent issues of importance for New Zealand teachers, social workers, counsellors, mental health workers and all who work with migrants.

\section{Afrikaner migration to New Zealand}

Statistics South Africa does not collect any information on emigration. Data regarding South African emigration can only be derived from statistics gathered by the host countries. OECD statistics shows that South African-born people mostly migrated to Britain $(227,000)$, Australia $(155,690)$, USA $(78,616)$, New Zealand $(41,676)$ and Canada $(38,310)$. These statistics exclude children born to South African migrants (Politicsweb, 2014). This number of South Africans migrating to New Zealand justifies research into issues that would help South Africans settle and contribute to New Zealand's economy and society (Pietersen, 2000; Pernice, Trlin, Henderson and North, 2000).

Officials in South Africa classify all people of Caucasian race/European descent as 'Whites'. Immigration New Zealand statistics classify the above people as 'White South Africans' regardless of cultural group or language (Porter, 2006).

One of the cultural groups classified as 'White' in South Africa are Afrikaners. They are the result of colonisation in which 'the European settlers lost their attachment to their countries of origin, and with the blending of genes, cultures and languages - Dutch, German, French, Malay, Indigenous and African, and with the influence of the African landscape, became the Afrikaners' (Bain, 2005, p. 4). Afrikaners are recognised in South Africa as an ethnic 
group with a distinctive language and culture, Afrikaans. Although this paper focuses on one cultural group of migrating South Africans, Rajcic (1999) notes that there are common issues facing migrants speaking a different language than that used in the host country.

\section{Reasons for migration}

The reasons for migration range across a spectrum from those who are pushed from their homeland by circumstances, to those who choose to migrate in search of better opportunities for themselves and their children (De Souza, 1995). Migration is motivated by push and pull forces (Kunz, 1973; Berry, Poortinga, Breugelmans, Chasiotis and Sam, 2011). At one end of the scale are refugees who are motivated by push forces which make migration involuntary for survival. Returning home is not an option. At the other end of the scale are willing migrants who are pulled by a better lifestyle, employment opportunities or family members who have gone before them and may not have the option to return home.

The South African push factors have traditionally been put down to high levels of violent crime, fear, corruption of government officials, decay of state services and demands by ANC politicians to apply punitive sanctions to companies who promote whites to senior positions. The 2012/2013 crime statistics in South Africa show that violent crime causing trauma, fear and outrage have increased. Murder is internationally seen to be indicative of the country's instability, as at 47 murders daily, the South African murder rate, per capita, is now five times higher than the global average (Africa Check, 2014).

The New Zealand pull factor for South Africans is its immigration policy, job opportunities and reputation of being a safe and welcoming society. Although the pull factors are attractive, Harrison and Nortje (2000) distinguished that the push factors were the deciding aspect. South African migration is therefore not totally voluntary. Although South Africans have the option to return to their native country, the push forces would make return a less viable option (Pernice, et. al., 2000).

Bain (2005) concludes that Afrikaner immigrants are anticipatory, events-related refugees. They anticipate a situation where Afrikaners would become involuntary refugees, they fear or have experienced life-threatening violent situations, and consider it perilous to return to South Africa. She states that anticipatory refugees have particular needs that deserved to be recognised, understood and supported by their host country.

\section{Culture shock}

The experience of moving from one cultural environment to another can produce shock, which pervades all areas of migrants' lives. Igoa (1995) describes culture shock as cultural disorientation when people are transplanted from their familiar cultural environment to a different culture, where the migrants do not understand subtle cues and symbols of social intercourse, behavioural rules and codes. The grief and loss experience, stress about the changed environment and demands of settling into a new culture, such as working, learning and socialising in a second language, all cause a high level of anxiety in both adults and children. Ting-Toomy and Chung (2005) describe culture shock as an extreme emotional experience in which migrants experience behavioural confusion and disoriented cognitive functioning. Immigrants have to adapt from identity security and 
familiarity to identity insecurity and unfamiliarity (Sawicky, 2011). A gradual identity transformation takes place that leaves the immigrant with a higher degree of identity vulnerability. This vulnerability leads to migrants experiencing problems possibly unforeseen at the time of migration.

\section{Managing culture shock}

Culture shock needs to be identified as part of a natural process, and steps to manage it can be put in place by both the immigrants and the host country. Ting-Toomy and Chung (2005) recommend that conscious management of culture shock and addressing identity-vulnerability is imperative in the process of adapting in the host country. The following factors assisted with the psychological adaptation and acculturation process described by Ward, Bochner and Furnham (2001, p. 45) as:

... a learning experience which assists with the acquisition of appropriate social skills needed to negotiate life in the new setting, and the management of stress-provoking life changes, which requires multiple coping strategies to facilitate psychological well-being ... both the culture learning and the stress and coping approaches portray persons as actively responding to and dealing in constructive ways with their problems.

The attitude of the host country also impacts on how migrants manage their shock reaction. The Centre for Applied Cross-Cultural Research's research findings suggest that $89 \%$ of New Zealanders were positive about a multicultural New Zealand. Eighty-two per cent of New Zealanders believe that migrants should adopt New Zealand culture while maintaining their own (Ward, 2012).

Migrants use different strategies to adapt to a different culture and cope with the disorientation of being in a strange cultural environment. It seems that culture shock can be consciously managed with social support put in place by both the hosts and migrants.

Social support can provide a buffer against stress whilst enhancing the coping strategies of the individual to deal with potentially harmful situations. Such support increases individual well-being and increases the feeling of control over the situation (Pietersen, 2000). In recent years, social media sites such as Facebook's SafriKiwi have become an active support system to migrants and people who are considering, or are in the process of, moving to New Zealand. On the other hand, migrants who realised they made a mistake by moving away from South Africa support each other in the Facebook forum Return to South Africa. Online newsletters, such as Brokkies, which advertises South African businesses, cultural events, concerts and church meeting times, help migrants to make face-to-face social contact with other migrants.

There are different theories about the ways immigrants adjust to migration. Berry identified four different strategies individuals may use to achieve acculturation:

When non-dominant ethno-cultural groups do not wish to maintain their cultural identity and seek daily interaction with other cultures, assimilation is the emphasized strategy. In contrast, when non-dominant ethno-cultural individuals place a value on holding on to their original culture and at the same time wish to avoid interaction with others, separation is the chosen alternative. When there is an interest in both maintaining one's original culture and interacting 
with other groups in daily life, integration is the favoured option. In this case, some degree of cultural integrity is maintained while, at the same time, the individual as a member of a cultural group seeks to participate as an integral part in the larger social network. Finally when there is little possibility or interest in cultural maintenance (often for reasons of exclusion or discrimination) marginalization results (Berry \& Sam, 2013 p. 152).

\section{Grief and loss}

Migrants experience a range of losses, such as familiarity with the natural environment, a feeling a belonging to a cultural group, a historical belonging to a country, to loss of contact with friends and family. Grief is a natural reaction. Migrants use different strategies to cope with these losses. These strategies determine whether they assimilate into the New Zealand society or separate and live as outsiders.

As in any grief and loss situation, immigrants experience an emotional reaction to immigration. Immigrants sometimes feel:

...that somehow we were forced into emigrating, that we had little choice in the matter. We know that the South African economy is shot, we know that safety and security had become a priority, but still there is anger at the pain of dislocation (Harrison \& Nortje, 2000, p. 13).

Harrison and Nortje surmise that the personal history of South Africans is very different from the average New Zealanders' experience. They find that New Zealanders have a limited capacity to understand their often violent and traumatic past experience. This can lead to a sense of isolation and loneliness. Messina \& Lahav (2006) state that the distance between the two countries also has a grief and loss impact. The financial cost of travel to the country of origin on a 'need to' or regular basis for an average income family is prohibitive. Missed rituals such as funerals and celebrations are then part of the cost of migration.

Reyneke (2004) identifies three different strategies to cope with this grief. On the one end of the spectrum migrants cope with their grief by vilification of South Africa. To justify the loneliness, financial, social, cultural, spiritual and personal losses, South African society is remembered and talked about negatively. The more reasons immigrants can provide about why New Zealand is a better country to live in, the easier it is to remain convinced about the validity of their migration decision.

On the other side of the spectrum, some South Africans react negatively towards the patriotism and pride of New Zealanders. Everything in New Zealand is compared in a negative light to the nostalgic memories of the South African society. These people tend to form an exclusive circle by having mainly South African friends, buying mostly imported South African foods and frequenting businesses run by South Africans.

In the middle of these two extremes South Africans cope with their loss and grief by acknowledging the negative aspects in South Africa that were a 'push' factor as well as the 'pull' factors from New Zealand. They balance the positive and negative memories. They acknowledge positives such as New Zealand having lower levels of racism, crime, unemployment and HIV / AIDS infection. They appreciate New Zealand's strong welfare system, first world economy, and admit and accept that New Zealand has its own intrinsic and unique set of problems. 


\section{Mental unwellness as a consequence of migration}

Various studies have explained the link between the severe stressors of migration and the deterioration of mental health experienced by immigrants. Madianos (2010, p. 103) suggests that the deterioration is offset by the difficulties associated with continuous contact with a different culture and that migrants consequently have to change their own thinking and behaviour patterns. Pernice (2010, p. 235) reports that South Africans are able to find employment in New Zealand, but that their mental health was not better than unemployed immigrants from other cultures who experienced more discrimination when seeking employment. She surmises that because South African migration is not as voluntary as other immigrant groups in New Zealand, that they were pushed, not pulled. Pernice (1987) found that migrants' mental health is affected by both the geographical and climatic changes in the environment, in addition to cultural and psychological factors. Eisenbruch (1991) criticises the diagnostic criteria used by psychiatrists and psychologists as culturally insensitive. Symptoms which can lead to the diagnosis of post-traumatic stress disorder can also be symptoms of the process of cultural grieving. However, Pernice et. al. (2000) assert that migrants have a higher risk of mental health issues at different stages of their settlement into a new country. An initial euphoric stage is followed by increasing mental health difficulties that can reach a crisis at any time from six months to six years after arrival. Further research into diagnostic criteria seems to be necessary to identify cultural grieving with culturally sensitive testing.

Pernice and Brooke (1996) found that the degree of stress is related to the circumstances resulting in the decision to migrate, the attitude of the migrant towards acculturation and the support or discrimination experienced in the new country.

\section{Language}

As people receive communication they interpret it according to their own cultural viewpoint and standards, which may not be what the speaker from another culture intended. There are covert means of communication, unspoken codes, preconceptions and stereotypes. Lee (2003 p. 22) states that a 'person's culture teaches them how to communicate, think, interact, and interpret other's communication.' Therefore, 'gestures in one culture can mean something entirely different in another cultural context.'

Afrikaans is one of the 11 official languages in South Africa (Nationmaster, 2014). English is taught as a second language in Afrikaans medium schools usually by Afrikaans teachers. The nuance is that the mastery of a language is not only in the vocabulary, but includes the cultural meaning of words and idiomatic phrases. The formation of a language is also influenced by the worldview and values of the culture that shaped it (Ting-Toomy \& Chung, 2005, Jackson, 2014).

Afrikaners trying to understand the verbal and non-verbal communication in New Zealand find it stressful. The English dialect used in South Africa (often called South African English) is not unified in its pronunciation, but can be identified by many loan words from Afrikaans, Koi, Zulu, Malay and other African languages. Some Afrikaans words like trek, commando, aardvark and apartheid, have seeped into the world of English usage. In the same way, New Zealand English incorporates Maori words like hui, marae, whanau, aroha and hangi. 
Although English is a shared language between New Zealand and South Africa, colloquialisms and accents differ; New Zealanders tend to speak very fast for the Afrikaner who has a second language command of English. English South Africans find the Kiwi accent easier to understand than their Afrikaans-speaking counterparts. Some Kiwi words and phrases have different meanings in South African English. Consequently, many South Africans have been embarrassed by bringing their own crockery to social events, not understanding that 'bring a plate' implies 'with food on it'. Parents mistakenly send children to school with togs (rugby boots) instead of togs (swimwear) and being invited over for tea meant that migrants may arrive mid-afternoon, expecting a cup of tea, not an evening meal!

Having to work, learn and socialise in a second language can be mentally and emotionally tiring. The loss of opportunity to express oneself adds to the overall feeling of alienation and stress.

The inability of migrants to discourse in their first language presents complications for the migrant and people in the host country who assist them. Being immersed in an English-speaking society can lead to communication problems for Afrikaners. The effect of hearing English in a different accent than what was spoken in South Africa, as well as different cultural cues and social standards, may enhance the feeling of being a stranger in a strange land.

\section{Immigrant children}

Cultural factors shape child-rearing practices. There is also interaction between the institutions and laws of a country and the social structures of child rearing. New Zealand examples of this interaction would be the 'Anti smacking' bill that was on the political agenda in 2006-2007 as well as the practice of Family Group Conferencing.

Children who migrate are also affected by the shock and stress of migration. They need to adapt to being immersed in an environment in which they have to speak a second language and cope in an environment where the cultural code and communication cues are different. In addition, children are affected by the way their parents cope and manage the transition from one country to another. They react to the emotional state of their parents while the stress of migration may limit parents' capacity to make their children feel loved and safe (Harrison \& Nortje, 2000). Children may sense their parents' insecurity, instability and inability to nurture them. Children may also judge their parental culture, language and values inferior to the host culture (Igoa, 1995).

According to Galler and Sher (2010), adolescents have a higher level of depression and poor mental health. They ascribe it to migration stress in an already stressful life stage. Migrant adolescents have to cope with the loss of their peer group and adjust to a new school and language. With their parents having to cope with their own acculturation, adolescent children may lose their capable and reliable parent. In the life stage where adolescents must find their own identity, they lose their cultural identity and strive to achieve acculturation.

Parents are often unaware that their offspring are going through their own phases of grief and adaptation. As children and young people are usually faster in learning a new language and find it easier to make friends, their difficulties are assumed to be minor in 
comparison with parents struggling with physical survival (Rajcic, 1999). The children's seemingly easier and faster adaptation to the new cultural environment may sometimes lead to role reversal, where the parents become dependent on their children to translate and explain communication and experiences (Adams \& Kirova, 2007).

Adams and Kirova (2007) also found that children use their own strategies to negotiate between the differences of their known culture and the host culture. These strategies often include watching television to learn about the host culture. This enables them to have conversation topics with their peers at school, learn the host language and work hard to achieve at school. Often, migrant children will advise newly migrant children on how to negotiate within the cultural changes, which indicates they have evaluated which strategies are more effective in assisting their acculturation. Watts, White and Trlin (2002) found migrant children and young people have all the normal stressors accompanying growing up and moving to independence. However, they also have the added stressors of adapting to a new culture and country, as well as coping with the grief and isolation associated with moving away from the familiarity of their own country, culture and support networks.

Children of immigrants often live in two worlds. At home they want to keep their parents happy with culturally appropriate behaviour, while they need to modify their behaviour at school to fit in. By being immersed in two cultures, immigrant children have to adapt to both, and this may negatively influence their sense of belonging to either culture (Pietersen, 2000). Conversely, some Afrikaner parents actively discourage their children speaking Afrikaans and disconnect from their Afrikaner culture. This leads to a loss of belonging and personal identity (Bain, 2005). Rivera (1997) noted the dilemma of immigrant mothers:

When you are away from your homeland, who passes on the values of your culture, of your family, of your ancestors, of the old people? If you don't pass on your traditions, they [the children] would not know them, because they are not there [in your country] to live them. So I am the transmitter of all the values. Perhaps now they would only keep them in their heads, but when I die they would use what I've given them in some way (1997 p. 106).

Children are directly affected by migration. Often they miss out on parental guidance and support in the process of adapting to their new cultural environment. They devise their own methods to understand and fit into their social group and often have to negotiate between the expectations of the culture in society and the culture at home.

\section{Spirituality and religion}

McCarthy (2005) believes that all cultures share a connection between land, religion, spirituality and culture. He argues that the foundation of spirituality is the universal link towards ancestral land. By migrating, that sense of feeling grounded, the turangawaewae, is lost. The sounds, smells and vistas of childhood are gone and replaced by an equally beautiful but totally foreign environment. Patterson (1992) reflects on the spiritual effect of being uprooted from your own land to another place on the earth:

Spiritually and psychologically we need to know that we have a rightful place on the planet, we need to know that we belong here, we need to know that we are significant parts of a significant whole. Without this sense of belonging life in the lands we live is meaningless (Patterson, 1992, p. 29). 
Being part of a religious or spiritual group leads to a feeling of belonging. Such a group can become a substitute family, a place where social events and opportunities to make friends are created. Schiller and Caglar (2008) found that the Christian identity may be a way of settlement and a social citizenship in a new country. Although many Afrikaans Christians adapted and fitted into English churches, there are many who were not able to worship in their second language and felt they did not belong in an English congregation. The Afrikaans Christian Church in New Zealand was started on the North Shore in 1998 after some Afrikaner migrants' experience of not feeling comfortable or 'at home' in English language churches. There are now Afrikaans churches in several cities in New Zealand, as well as website services for Afrikaners not able to physically attend (Afrikaanse Christenkerk, 2014):

Joining a faith community provides an immediate social network for many migrants and frequently gives migrants a place to belong and a new sense of 'family' and 'home', particularly where they have left these two things behind in another country (Butcher, 2007).

Literature on spirituality and religion in connection with migration to New Zealand is lacking.

\section{Discussion}

Afrikaners mostly migrate because they anticipate a situation where living in South Africa will become intolerable, or personally experienced that South Africa has become an undesirable place to live. New Zealand is a popular migration destination for Afrikaners, but the differences between New Zealand and South Africa are often underestimated. This shock of having to live, work and learn in a different society with different cultural codes and rules causes what is commonly referred to as culture shock. Migrants give up everything that is known and dear to them in the process of moving to another country. These losses lead to a process of grieving for what was left behind. Children of migrants are often not supported by their parents or professionals, as children's ability to become fluent in a new language and make friends is misinterpreted as meaning they are not experiencing the similar grief, alienation and shock of their parents. All of these stressors may lead to deterioration in the mental health status of migrants. Techniques have been identified which migrants use to adapt to the host country's culture. Afrikaners who belong to churches may have an immediate social network and a feeling of belonging.

Eight key themes have been identified: the reasons for migration, culture shock, managing culture shock, grief and loss, immigrant children, language, mental health, and spirituality and religion. The discussion focuses on the implications of these themes for supporting migrant children and their parents

\section{Implications for schools and social services}

Schools can play a major role in assisting migrant children and their parents. Teachers should identify what type of support a child needs or call on support services such as social workers and health professionals. These professionals can help the child to understand that the old culture need not be rejected in the quest to fit into the new one.. The new culture can be integrated within the old cultural self. To enable this, the social service professionals and the classroom teacher should acknowledge that the child or young person is in transition, 
bringing to the class a unique cultural history. Attention should be given by educators to addressing the concept of bi-culturalism for immigrant children and their families. The strain of dealing with identity confusion, and differences in language and culture needs to be recognised at school and in the organisations or clubs children join. This would help immigrant children to adjust to the education structure of a different culture. Professional development courses can assist teachers to learn about their students' native countries and history, and include the parents in the acculturation and education process.

School liaison teachers and social workers in schools could initiate contact with parents and explain to them what is expected of parents in New Zealand, as well as what would be expected of children. Migrant parents need to be informed by the school about what is expected from parents; schools can explain the teaching and learning styles used in New Zealand classrooms and the homework expected from pupils.

Migrant children who do not have English as a first language have the added challenge of having to translate previous knowledge into English. This may or may not be achieved, depending on the ability of the child in English. Migrant children may benefit from one-onone revision to ensure that each child is able to transfer their previous learning into the new school system and into English. Attention should be given to spelling and grammar as part of an induction to school as migrant children may not have a solid grounding in English.

Parents and children would benefit from an explanation of what is expected of parents and children in New Zealand schools. Children who have learned in Afrikaans are not always able to transfer their learning immediately to English by themselves. Fear and stress in a new land can be hindrances and should be taken into consideration by teachers when a student's progress is assessed.

Schools, teachers and support services should be aware that pupils from Afrikaans medium schools are used to a higher level of discipline and expectation that pupils show respect to people in authority. Teachers need training in understanding culture shock for children. They can ease the culture shock for pupils by making migrant children aware that the New Zealand school culture is different from what they are used to and help them understand social codes and manners of New Zealand children.

Many migrants could benefit from accessible information on the impact of culture shock to migrants, as well as information on how to cope with migration losses and corresponding grief. Rajcic (1999) noted that the issues facing immigrants speaking a different language to that of the host country would be universal and apply to other immigrant groups as well. Porter (2006) asserts that, as New Zealand is one of the few countries in the world that actively encourages immigration as a way of increasing economic and population growth, research that creates transferrable evidence would be most valuable for practitioners who increasingly work with more ethnicities in New Zealand. Books and guidelines on how to cope with migratory stress, grief and culture shock would be of great assistance to migrants of all cultures and the practitioners who work with them. This is an identified need and an opportunity for writers to publish 'self-help' books on dealing with grief for migrants.

Potocki-Tripody (2002) recommends that social workers should become skilled in cross-cultural social work and have specialised knowledge about the resettlement process 
More research and training should be available for social workers in the New Zealand context to help them meet ANZASW practice standard 3, which states that: 'The social worker demonstrates competence to work with different ethnic and cultural groups in Aotearoa New Zealand'.

Adaptation to a new country demands migrant families re-interpret their past to make sense of the present, to make it possible for them to anticipate a future. Migrant families have to analyse their interpretation of citizenship and patriotism, traditions, familial relationships and child-rearing practices. In this process, social workers and counsellors need knowledge of evidence-based practice, should use the strengths-based model, have non-discriminatory standards and cross-cultural competency. Nash, Wong and Trlin (2006) support this notion, stating that with increased globalisation a new field of social work practice is created which deals with issues regarding migration and resettlement. They advocate the need for social work training to include cross-cultural practice, social integration, human rights and advocacy.

Social workers need to improve networking with agencies that work with migrants, to better support migrants, and heighten their awareness of human rights and advocacy. In addition, the importance of symbolic gestures needs to be recognised as a counselling tool. Planting a tree for example may be a symbol of putting down new roots and growing together, each year a little stronger. Symbolic gestures could be a part of settling into the new country and could be a tool used by professionals.

Potocki-Tripodi (2002) advises that social workers should be aware of the ongoing grief process and be alert that some overt actions of migrants, such as anger, may be expressions of grief. All support services should explore and check the need for counselling, emotional support and networking, both for the adults and the children in the family.

Adequate mental health care is a key issue in positive settlement. Although there have been changes and new initiatives in the last few years, there is still a profound lack of knowledge and services available in New Zealand to meet the needs of immigrants and refugees. South Africans who fall in the anticipatory migrant classification may have witnessed or experienced violence in some form and may have come to New Zealand with grief, fears and post-traumatic stress. Their backgrounds must be taken into consideration when assessing for mental health problems and in consequent interventions. Reactions such as distrust of strangers, a high degree of vigilance and an underlying fear and expectation of violence may be diagnosed as symptoms of a mental health disorder by a New Zealand health professional, while in South Africa this would be considered normal and essential for survival.

Communities can celebrate the diversity of cultures. This is associated with Waitangi Day in some communities and with cultural festivals such as Diwali in other communities. Jason Kerehi, chief executive of Rangitane o Wairarapa, initiated citizenship ceremonies to be held on local marae. Welcoming manuhiri who settled in the area with a powwhiri is part of tikanga Māori, and invites migrants to become part of the community. The citizenship ceremony emulated the desire of the local people to welcome new people. This ceremony creates an opportunity for migrants to experience tikanga Māori and being on a marae. This unique citizen's ceremony, hosted by the iwi and the Masterton District Council, is 
experienced in a very positive way by migrants. Some come dressed up in their traditional costumes and when they have an opportunity to mihi whakatau they get the opportunity to introduce their heritage and home and sing in their native tongue. For some it would be the first opportunity to introduce themselves to the community. Mr Kerehi said that one woman burst into tears, saying that this is the first time that people welcomed her and it felt as if she came home. Word of the way migrants are welcomed in Wairarapa has spread and other iwi and district councils such as Waitakare are now also using the pōwhiri to integrate migrants to the community they live in.

Rivera (1997) found that immigrants were aided when they had an opportunity to connect with migrants from the same cultural group. If people who speak the same language could support migrants on their arrival, with culturally appropriate assistance, many of the adaptation problems faced by migrants can be avoided. What to pack for children's school lunches or how to keep your house warm in winter are examples of knowledge New Zealanders take for granted.

Adaptation to a country that has the same colonialist roots is sometimes mistakenly seen as easy. Afrikaners often under-estimate culture shock when arriving in New Zealand, as the English language (albeit a second language to Afrikaners) and many European customs are shared. However, the European colonists in South Africa and in New Zealand developed distinctive ways of verbal and non-verbal communication; the geographical location, the political history and indigenous people of each country influenced their separate cultural development. Afrikaners have to adapt to a culture that may have a superficial appearance of sameness, but is in reality totally different.

In conclusion, there is a need for migrants to become more informed about culture shock and the stress of migration, in order to be able to be prepared for what awaits them. A broad range of stressors from loss of finances, status, close relationships, to fear of the unknown, a sense of isolation, and new geography and climate can lead to social, economic and psychological costs higher than were originally expected, and more time needed to adjust than was ever imagined.

Antilla (1995) writes about the man who sits and waits for his soul to arrive: This is true for all immigrants. For some the soul never arrives. In many cases it takes three generations to become a full member of the new society.

\section{References}

Adams, L.D. \& Kirova, A. (Eds.) (2007). Global migration and education. Schools, children and families. London: Lawrence Erlbaum Associates.

Afrikaanse Christenkerk in New Zealand (2014). Welkom by die Afrikaanse Christenkerk in New Zealand. (Translated: Welcome at the Afrikaans Christian Church in New Zealand.) Retrieved 18 October 2014 from www.afrchristenkerk.co.nz.

'AfricaCheck: Sorting facts from fiction.' Retrieved 19/9/2014. http://africacheck.org/factsheets/factsheet-south-aficas-official-crime-statistics-for-201314/\#sthash.vWuUDhXk.dpuf.

Antilla, O. (1995). Some thought on the process of immigration. Journal of the New Zealand Association of Psychotherapists, 1 (June), 77-79.

Aotearoa New Zealand Association of Social Workers (Nov 2014). Practice Standards. Retrieved 11/2/2015. http: / / anzasw.org.nz/documents / 0000/0000/1653/ANZASW_Social_Work_Practice_Standards_Publication.pdf.

Bain, L. (2005). The Great Trek: From Africa to Pacifica. An exploratory study of Afrikaans immigrants to New Zealand. A research report in partial fulfilment of the requirements of the Master of Social Work Applied degree at Massey University: Palmerston North. 
Berry, J.W., Poortinga, Y.H. Breugelmans, S.M., Chasiotis, A. \& Sam, D.L. (2011). Cross-cultural psychology and research and applications, 3rd ed. Cambridge: Cambridge University Press.

Berry, J.W., \& Sam D.L. (2013). Accommodating cultural diversity and achieving equity: An introduction to psychological dimensions of multiculturalism. European Psychologist, 18(3), 151-157.

Butcher, A. (2007). Not a Western story! The Christian faith and migrant communities in New Zealand. Aotearoa Ethnic Network Journal, 2(2).

De Souza, R. (2005). Working with refugees and migrants. In D. Wepa (Ed.). Cultural safety in Aotearoa New Zealand. Auckland, New Zealand: Pearson Education.

Dwivedi, K.N. \& Varna, V.P. (1996). Meeting the needs of ethnic minorities children. London: Jessica Kingsley Publishers.

Eisenbruch, M. (1991). From post-traumatic stress disorder to cultural bereavement: diagnosis of Southeast Asian refugees. Social Science E Medicine, 33(6), 673-681.

Galler, D. \& Sher, L. (2010). The effects of immigration on the mental health of adolescents: Depression, post traumatic stress disorder, substance abuse, delinquent and suicidal behaviour among immigrant youth. In L. Sher, \& A. Vilens (Eds.). Immigration and mental health: Stress psychiatric disorders and suicidal behaviour among immigrants and refugees. New York: Nova Science Publishers.

Harrison, J. \& Nortje, S.A. (2000). New life in New Zealand. Auckland: The Reference Publishing Co.

Hemming, E. (2013). Scatterlings, a tapestry of Afri-Expat tales. Australia: Xlibris Corporation.

Igoa, C. (1995). The inner world of the immigrant child. New York: St. Martins Press.

Jackson, J. (2014). Introducing language and intercultural communication. New York: Routledge.

Jones, M. (2007). My sons deserve better. TVOne on 23 June, 2007. ca 46min. Made for Massey University's education purposes under licence from Screenrights.

Kunz, E.f. (1973). The refugee in flight: Kinetic models and forms of displacement. International Migration Review, $7(2), 125-146$

Langenhoven, P. (2014). Brokkies: An Afrikaans e-newsletter from Kiwiland. Retrieved 19/10/2014 from brokkies@ afrikaansnz.net.

Lee, M.A. (2003). First year here: A study of non-New Zealand-trained registered nurses in their first year of practice in New Zealand. Albany: Massey University.

Madianos, M.G. (2010). Acculturation and mental disorders among immigrants. In L. Sher, \& A. Vilens (Eds.). Immigration and mental health: Stress psychiatric disorders and suicidal behaviour among immigrants and refugees. New York: Nova Science Publishers.

McCarthy, D. (2005). Spirituality and cultural safety. In D. Wepa (Ed.). Cultural safety in Aotearoa New Zealand. New Zealand: Pearson Education.

Messina, A.M. \& Lahav, G. (2006). The Migration reader. Exploring policies and politics. Colorado: Lynne Rienner Publishers.

Nash, M., Wong, J. \& Trlin, A. (2006). Civil and social integration: A new field of social work practice with immigrants, refugees and asylum seekers. International Social Work, 49(3), 345-363.

Nationmaster (2014). http/ / www / nationmaster.com. Retrieved 21/10/2014.

Patterson, J, (1992). Exploring Maori values. Palmerston North: Dunmore Press.

Pernice, R. (1987). Mental health of refugees and immigrants in New Zealand. A thesis presented in partial fulfilment for the degree of Master of Arts in Psychology: Massey University.

Pernice, R. (2010). Successful use of mental health migration models: The New Zealand experience. In L. Sher, \& A. Vilens (Eds.). Immigration and mental health: Stress psychiatric disorders and suicidal behaviour among immigrants and refugees. New York: Nova Science Publishers.

Pernice, R., \& Brook, J. (1996). Refugees' and immigrants' mental health: Association of demographic and post-immigration factors. The Journal of Social Psychology, 136(4), 511-519.

Pernice, R., Trlin, A., Henderson, A. \& North, N. (2000). Employment and mental health of three groups of immigrants to New Zealand. New Zealand Journal of Psychology, 29(1), 24-28.

Pietersen, C. (2000). The role of personality and coping on the well-being of South African immigrants. A thesis in partial fulfilment of the requirements for the degree of Master of Science in Psychology at Massey University: Palmerston North.

Politicsweb (2014). How many South Africans have left the country? Politicsweb.co.za. Retrieved 16 September 2014. www.politicsweb.co.za/politicsweb/view/politcsweb/en/page71619?oid=318618\&sn=Detail.

Porter, S.A. (2006). Highly skilled South African immigrants in New Zealand. A thesis in partial fulfilment of the requirements for the degree of Master in Management at Massey University.

Potocki-Tripodi, M. (2002). Best practices for social work with refugees and immigrants. New York: Columbia University Press.

Rajcic, T. (1999). The little immigrants from former Yugoslavia: Possible problems of children after immigration. A research report presented in partial fulfillment of the requirements for the Masters in Social Work (Applied), Massey University.

Reyneke, C.J.S. (2004). ' $n$ Prakties-teologiese narratiewe navorsing ven die aanpassingsproses van ' $n$ gesin wat van Suid Afrika na Nieu-Seeland verhuis het. A thesis in partial fulfilment of the requirements for the degree of Doctor Divinitas. Pretoria: University of Pretoria.

Rivera, M.A. (1997). Contra viento y marea. (Against the wind and the tide) Latin American women in New Zealand: Resettlement experiences and issues. A thesis presented in partial fulfilment of the requirements for the degree of Master of Philosophy in the Department of Social Policy and Social Work. Massey University. 
Sawicky, W. (2011). We are not like other people: Identity loss and reconstruction following migration. In D. L. Harris (Ed.). Counting our losses: Reflecting on change, loss and transition in everyday life. New York: Routledge.

Schiller, N. G. \& Caglar, A. (2008). 'And ye shall possess it, and dwell there in.' Social citizenship, global Christianity and non-ethnic immigrant incorporation. In R. Danahay, \& C.B. Brettell (Eds.). Citizenship, political engagement and belonging. Immigrants in Europe and the United States, pp. 203-225. New Jersey: Rutgers University Press.

Ting-Toomy, S. \& Chung, L.C. (2005). Understanding intercultural communication. Los Angeles, California: Roxbury Publishing Company.

Ward, C. (2012). New Zealanders value a strong multicultural society. Retrieved 30 September 2014. http: / / www. victoria.ac.nz / cacr / about-us / diversity-issues / corruption-drops-as-incomes-rise-say-victoria-researchers.

Ward, C., Bochner, S. \& Furnham, A. (2001). The psychology of culture shock, 2nd ed. East Sussex: Routledge.

Watts, N., White, C. \& Trlin, A. (2002). Young migrant settlement experiences and issues in New Zealand: Two perspectives. Massey University: New Settlers Programme. 